\title{
Aeronautical Information Service-General Aviation Pilots interface in digital era
}

\author{
Roman Matyáš \\ Department of Air Transport, \\ Department of Air Transport, Faculty of Transportation \\ Sciences, Czech Technical University \\ Horská 3, Praha 2, 128 03, Czech Republic \\ matyarom@fd.cvut.cz
}

\author{
Andrej Novák \\ Department of Air Transport FPEDAS \\ University of Žilina \\ Žilina, Slovakia \\ andrej.novak@fpedas.uniza.sk
}

\begin{abstract}
Modern technologies and portable devices are part of our everyday lives almost two decades. This article describes how Aeronautical Information Service providers in Central Europe utilize modern technologies in the communication interface with general aviation pilots.
\end{abstract}

Keywords-Aeronautical Information Service, General aviation, preflight planning, briefing, NOTAM, AUP

\section{INTRODUCTION}

General aviation has significant history in countries of Central Europe. With growing commercial transportation trend and safety measures applicable to airline sector also safety standards for general aviation grow. Great reliability of aircraft systems leaves the most accident to be caused by humans. To lower the human error rate, we can integrate usage of modern technologies to all aspects of flight - from electronic stability and protection to synthetic terrain, MFD checklists up to preflight preparation via internet platforms. In the following text, all AIS portals communicating temporary changes to the general state (NOTAMs and AUPs) in Central Europe region are discussed and their pros and cons emphasized.

\section{AIS CHALLANGE WITH GA PILOTS}

Recent statistics of Air Accidents Investigation Institute (AAII) of the Czech Republic indicate that the main cause of ATM connected incidents in category of light aircraft up to 2250 $\mathrm{kg}$ is an Unauthorized Airspace Penetration (UAP). Some of the reasons why those, mostly general aviation aviators, made significant number of incidents could be:

- Loss of orientation during flight due to deteriorating meteorological condition

- Loss of orientation during flight due to navigation error

- Fear of communication with a controller

- Intentional UAP

- Insufficient preflight planning and briefing
According to AAII, total of 65 UAP events took place in the Czech airspace during 2015, as could be referred to the figure 1 . All the cases were classified as incidents, except one. [1]

\section{Unauthorised Airspace Penetration (up to $2250 \mathrm{~kg}$ )}

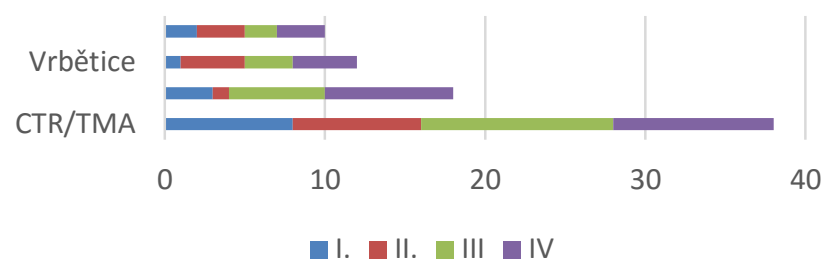

Figure 1. Structure of UAP in FIR Praha during quartals of 2015

\section{PROPER PREFLIGHT PREPARATION - ONE STEP CLOSER TO SAFE FLIGHT}

As was stated above, one of the factors of UAP is insufficient preflight planning and briefing. Typical GA pilot wishes to fly in CAVOK conditions for pleasure. He/she is mostly perfectly familiar with the surrounding terrain and airspace of home airfield and tend to underestimate preflight part of the flight itself.

The user friendly interface for GA pilots which provide all important information clearly and in one picture may be than considered as a tool enhancing ATM safety.

A1590/15

0)LKAA/QRPCA/BO/W/IV/000/070/490600N/0175600E/0004

A) LKAA

B) 1512111130 C) 1603312359 EST

E)TEMPO PROHIBITED AREA RADIUS 6KM PSN 490620,887N0175607,408E /VRBETICE/ EXCEPT POLICE FLT AND MIL ACFT. ENTRY PERMISSION WITH POLICE CR TEL: +420974 662 001. DEMOLITION OF EXPLOSIVES F)GND G)FLO70

Figure 2. Text of NOTAM concerning Vrbětice Temporary Prohibited Area [2] 
Number of UAP of Vrbětice (see text NOTAM A1590/15 above) may indicate the factor of unexpected. This Temporary prohibited area is not present on aeronautical chart and the village of Vrbětice is not on ICAO 1:500 000 chart itself either. For a recreational pilot who flies not so often may be very surprising the fact that he or she penetrated prohibited area.

\section{PREFLIGHT BRIEFING ISSUES}

Let us present an example of text versus graphical interpretation of NOTAM A1590/15 regarding Vrbětice temporary prohibited area. Despite the availability of plotted information, Vrbětice area was penetrated 12 times during last year (refer to Figure 1).

Figure 2 represents the text of NOTAM A1590/15, which is available to all crews through every channel. Without plotting it manually using GPS coordinates, there is very high chance to penetrate the concerned area while flying nearby. With five or more text NOTAMs en-route, the probability of making mistake somewhere between finding the right NOTAM and plotting it correctly, is quite high.

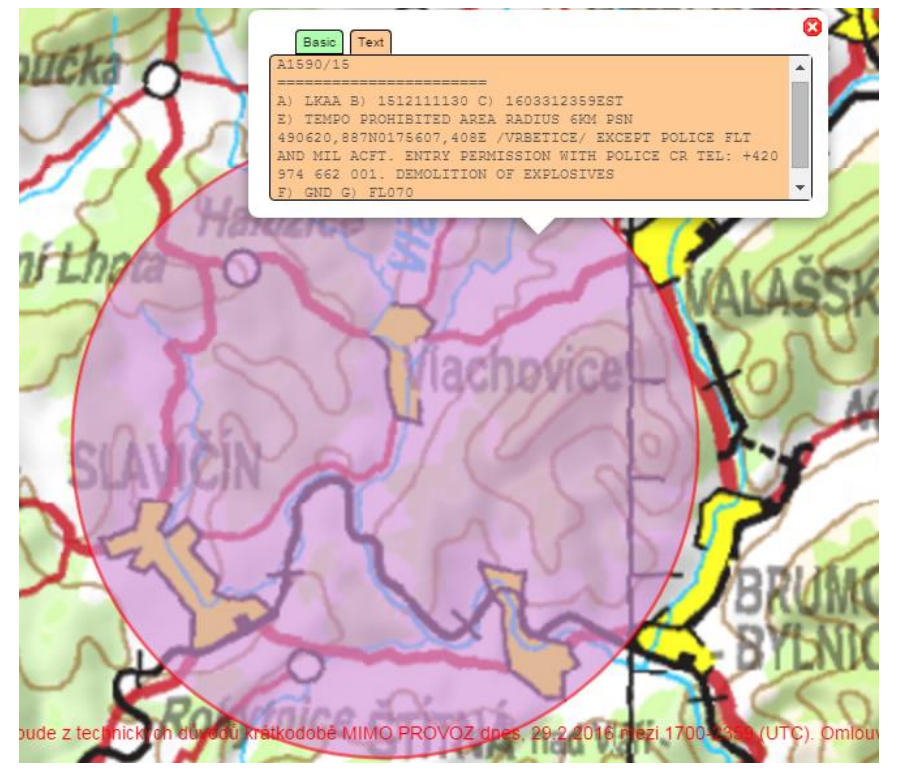

Figure 3. Village of Vrbětice is not plotted on the ICAO 1:500.000 aeronautical chart of the Czech Republic, that small it is. Figure is a cutout from AisView. [3]

However, there is a possibility to interpret the NOTAM graphically by means of modern technologies. Figure 3 shows plotted location of temporary prohibited perimeter which identifies it clearly. Detailed NOTAM description is shown after a click into the area.

\section{Possible ANSWER AND SOLUTIONS IN CENTRAL EUROPE REGION}

One of the possible solutions, as shown above, is to plot all the important information on one chart with intended flight path on it. There are several charged applications, however, we focus on AIS free web-portals in this article. Since VFR traffic up to 2t MTOW makes very low revenue (if any) for ANS providers compare to IFR heavy airliners, the AIS portal for VFR pilots is one of true proof of the company's commitment to safety.
In the following text there are described AIS web-based portals with emphasis on options of displaying important VFR flight information such as NOTAMs, prohibited, restricted and dangerous areas, as well as temporary reserved areas (TRA/TSA/MTA).

Registration is compulsory to display wide information in some cases, nevertheless, everything is free of charge, making graphic information financially unburdened. Description of particular state solution is covered in further paragraphs. We determined some important characteristics for VFR pilots' community such as:
a) user-friendly interface, and
b) mobile-view option

\section{A. Czech Republic}

Czech AIS has a web-based portal called AisView. It contains general information about airports such as runway system, com frequencies, elevation and link to the VFR manual for detailed information. Airspace structure of FIR Praha with location of temporary restricted and segregated areas (TRA/TSA), prohibited (P), restricted (R) and dangerous (D) areas are also shown on the chart. Sunrise, sunset as well as civil twilight times are very useful since VFR day conditions in the Czech Republic are defined from beginning of civil dawn to the end of civil dusk.

With green bar „Actual map display contains only guaranteed LKAA information" pilot may be confident of accuracy and legality of information.

User may add a layer of ICAO, topo and some other charts as shows figure of Vrbětice area in the previous paragraph. It is also possible to display route of flight.

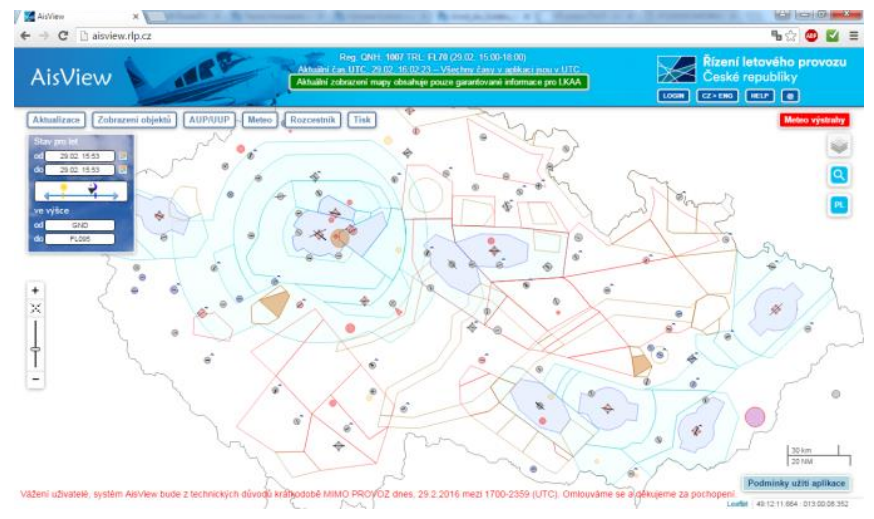

Figure 4. Desktop version of AisView, highlighted areas are active at the time. Time and altitude may be set and filtered in the top left part of the screen [3]

Ais View has a significant advantage, compare to the rest discussed solutions in other countries, and that is mobile view. Web is customized for portable devices and therefore the whole pack of information is available to pilots any time they are online literally in their pocket. 


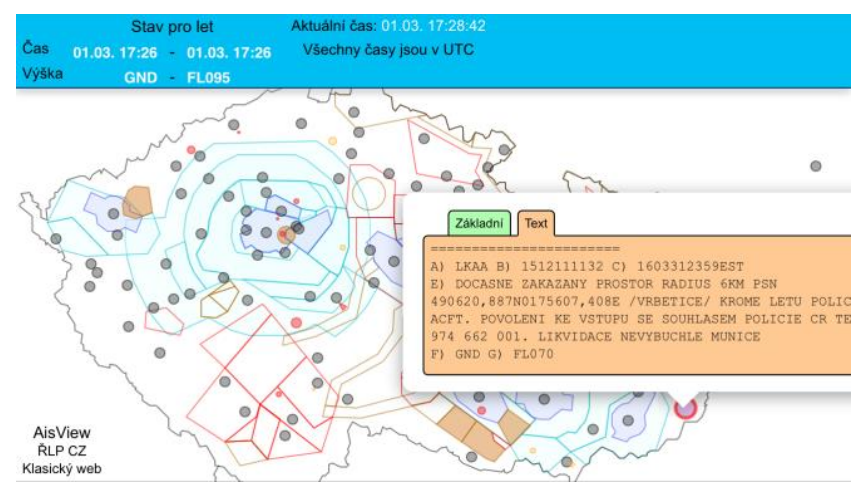

Figure 5. Mobile version of AisView, all important features functioning normally. [4]

\section{B. Slovakia}

Pilots in Slovakia have an opportunity to use briefing portal created by AIS Slovakia. Similarly as in AisView, there is possibility to receive detailed information about aerodromes such as runways, frequencies and some other useful information including, for instance, fuel types available, and sunrise and sunset times.

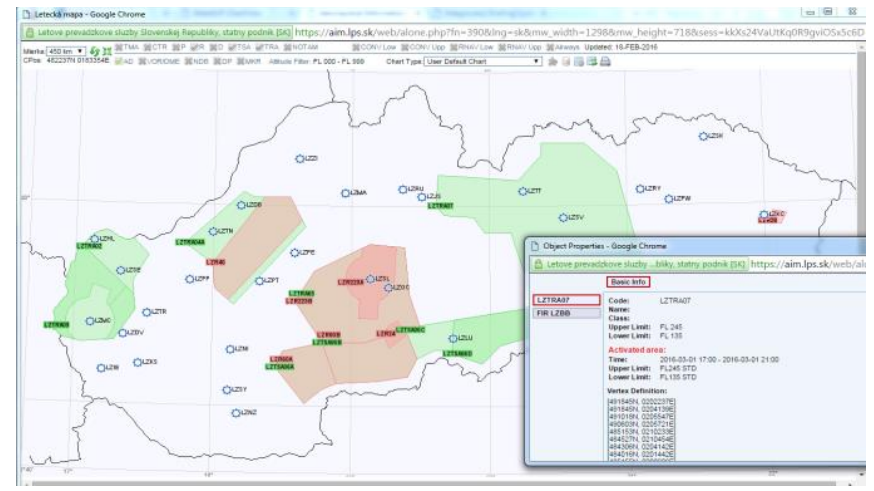

Figure 7: Desktop version of Slovak AIS portal - sufficient information for VFR flight is provided to the pilots [5]

The upper navigation bar allows to filter among displayed information - prohibited, restricted, dangerous as well as temporary reserved and segregated areas and NOTAMs. Therefore, it enables reliable and sufficient familiarization with safety information along the flight route. Flight route itself, however, is not possible to show on the map.
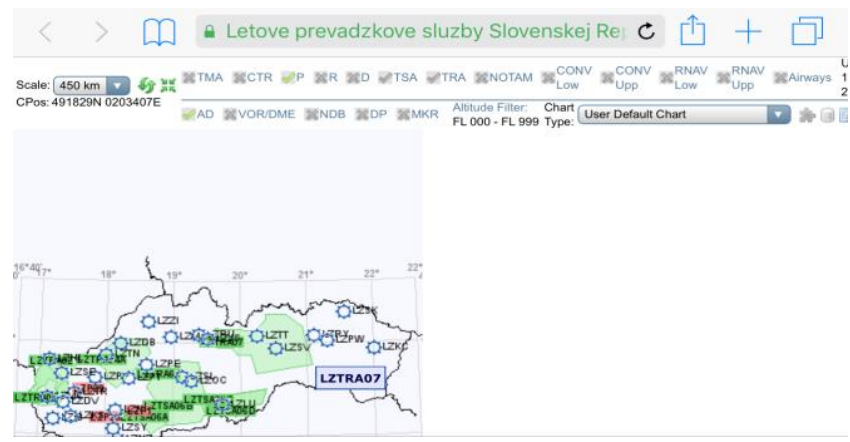

Figure 6. Mobile view of Slovak AIS portal - map is not accommodated to the screen size, only identifier (LZTRA07) is displayed without details [5]
Pilot carrying out the preflight briefing just prior departure appreciate the possibility to show activated areas only which are marked with letter A and highlighted in red.

Mobile view of web presents some room for improvement. Detailed information is not available on mobile platform, only the area identifier is displayed and the map is shown just on a half of the device screen.

\section{Germany}

German AIS provider - Deutsche Flugsicherung (DFS) created a tool which allows to prepare graphical NOTAM summary not just for domestic flight but also for flights to all surrounding countries. It has number of displaying options including ICAO and topo chart as well as flight route which may be modified directly by click-and-drag on the map.

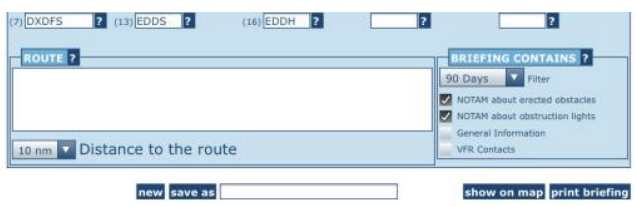

Press -print briefing-for legally valid proof pre-flight planning as per Art. (§) 27 of the Aviation Regulation (LuftVo/SERA).

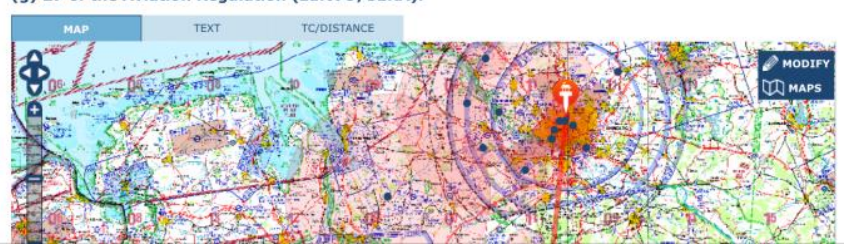

Figure 9: Mobile view of DFS portal does not include any information regarding highlighted NOTAM areas [6]

Displaying NOTAMs of surrounding states can be used with advantage during flight across borders. For example, to fly from France to the Czech Republic, pilot need to check only DFS portal and has comprehensive view of plotted NOTAMs enroute. Surprisingly, it is only possible to filter NOTAMs by their validity: 30 days, 90 days and ALL. There is no possibility to show activated NOTAM areas at particular time, neither R, TRA or TSA areas. Mobile view of portal is limited; details cannot be displayed.

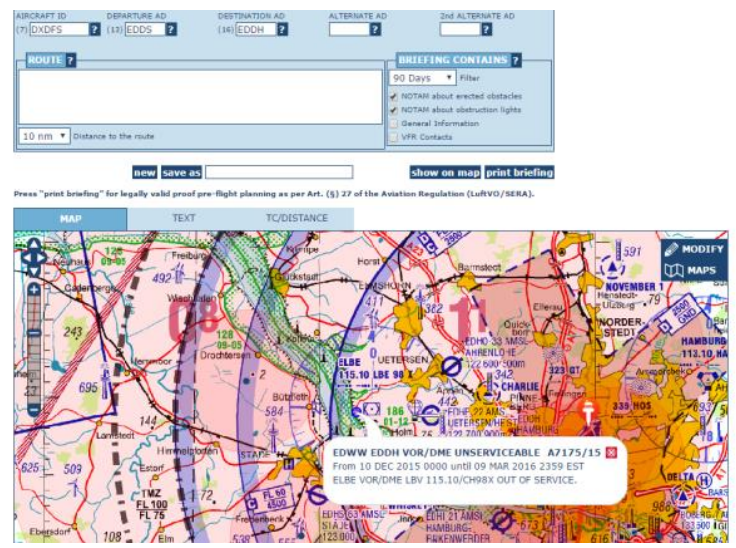

Figure 8. Desktop version of DFS portal - NOTAMs could be found at thei location with description [6]

Fortunately, German military AIS portal is able to plot KML files of active AUP areas on Google maps background. 
Identifier, description as well as activation times and administrator of the area are shown after clicking on the particular area.

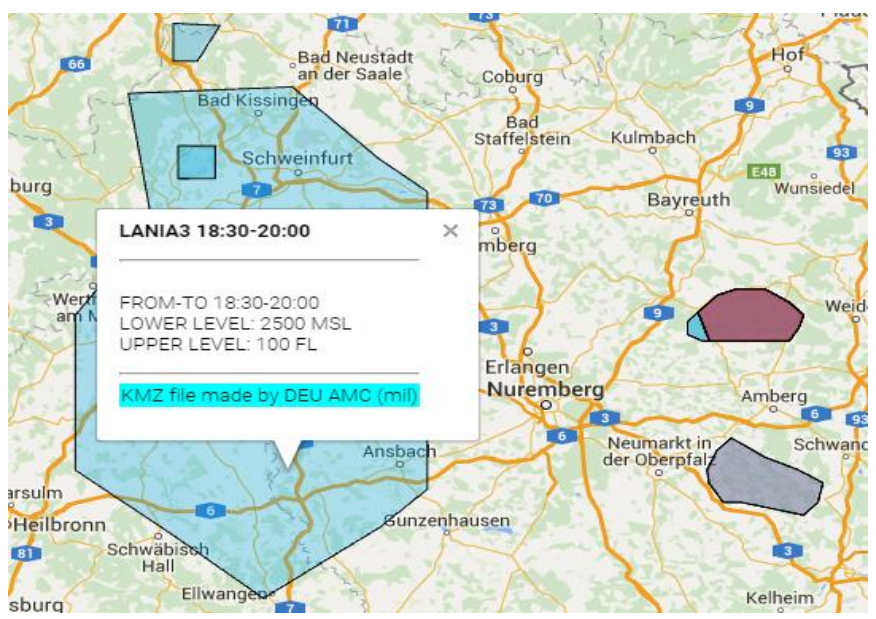

Figure 10: Military AIS portal shows current AUP areas as KML files with Google maps background [8]

\section{Austria}

Austrian AIS offers to pilots 3D model of airspace structure in KML file format. Google Earth is recommended for proper display. Regarding active areas (AUP), there is just static map with location of all active areas and their identifier on homebriefing server which offers charged subscription. On free AUP distribution page there is no option to tag anything or show description of any area interactively.

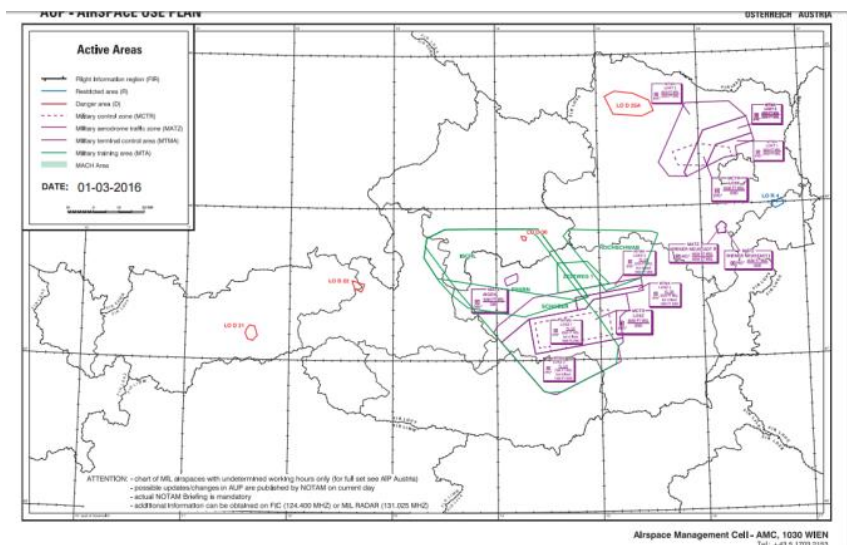

Figure 11: Active areas in Austria. Plain map, no interactive function [9]

Map may not be zoomed. Also the NOTAMs are not shown on the map. Austrocontrol puts pilots in situation where briefing is easier to make through German DFS portal which is able to show Austrian NOTAMs.

\section{E. Poland}

Polish pilots have also chart view of actual activated areas or restricted ones at their disposal. Unfortunately, there is no option of displaying NOTAMs and no zooming capability. Controlled airspace, cities as well as information service sectors may be displayed on the chart. Slider on the right side of the page is able to filter certain flight altitude and time periods, which is quite helpful.

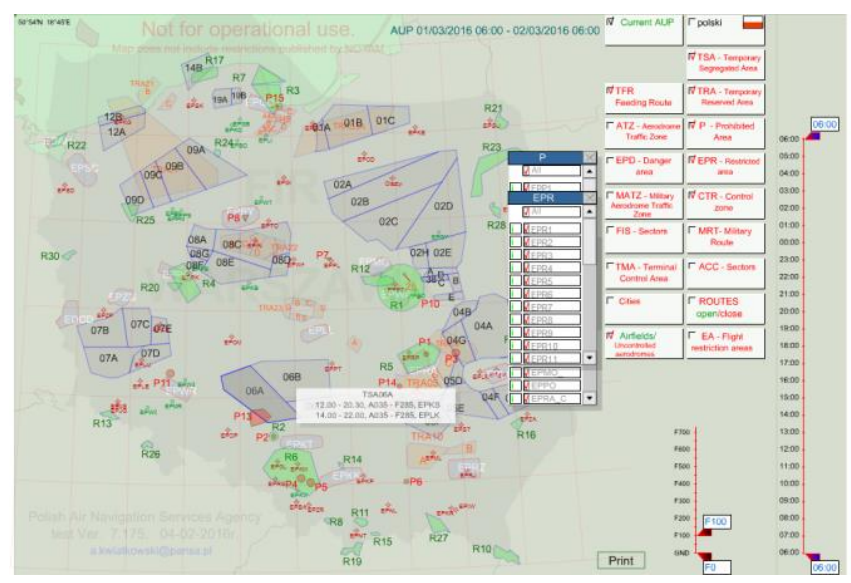

Figure 13: Polish PANSA portal - sliders in the right part allow pilot to filter information based on altitude and time [10]

PANSA portal map view is java scripted and was not possible to display it on a tested portable device.

Regarding NOTAMs, Polish ones could be easily handled similar to the Austrian NOTAMs, through the German DFS portal and easily get pilot oriented geographically.

\section{CONCLUSION}

Web based briefing systems are great tools that enhancing safety. Simplicity and clarity are fundamental elements for successful general aviation pilot preflight briefing. These qualities are achievable with modern technology. Portable devices such as iPads and mobile phones are able to bring the important information right into the pocket of every pilot. Trend of paperless cockpit may start to spread among general aviators. In the article we discussed Central European AIS portals and here is a brief summary as conclusion. From the perspective of integration of NOTAM and AUP information, and mobileplatform display, Czech AisView gained the best score. In 2016, portal should include flight plan filling feature, too. Regarding user convenience, AisView is on top level.

German DFS portal has huge advantage of direct flight plan filling and of displaying NOTAMs of surrounding countries which is very useful when flying across borders. Unfortunately, user has to switch to military AIS for graphic AUP information. Concerning mobile platform, details about NOTAMs cannot be displayed.

Slovak portal integrates NOTAM and AUP areas and generally is on high level, however, it lacks mobile device support and cannot filter displayed information by time and altitude.

Polish portal is able to show useful information about airspace structure, filters of altitude and time of flight may be added. Unfortunately, it does not integrate NOTAMs and was not possible to display the web page on portable device browsers.

Austrocontrol portal links to homebriefing service which is a prepaid service. AUP could be plotted on the chart, however, it is not interactive at all. 


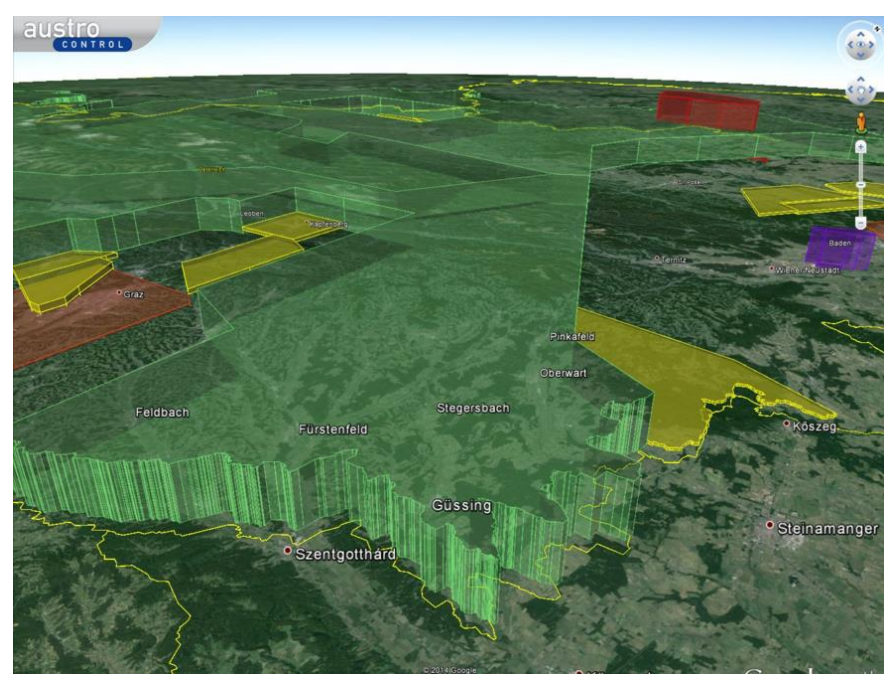

Figure 12: Interpretation of KML file - Austrian airspace structure at 3D presented in Google Earth [11]

Compare to the situation few years ago, there is a considerable effort of AIS providers to clarify and simplify the NOTAM and AUP information. It is therefore possible to anticipate further development of AIS-GA pilot interface that will, hopefully, bring lower numbers of UAP and NOTAM connected violation due to poor preflight preparation. Overall, this effort enhances safety level of general aviation over Central Europe.

In conclusion, here are two recommendations for VFR pilots to minimize UAP:

- Using of all available resources of aeronautical information with emphasis on graphical interpretation (plotted AUP and NOTAM)

- Continual communication (monitoring at least) of FIS frequencies during whole flight, especially to the unfamiliar areas

\section{ACKNOWLEDGMENT}

This paper was supported by the Grant Agency of the Czech Technical University in Prague, grant No.

\section{REFERENCES}

[1] ÚZPLN. Porada k bezpečnosti letů za 4Q 2015 a za rok 2015. In: ÚSTAV PRO ODBORNÉ ZIIŠŤOVÁNÍ PŘICIIN LETECKÝCH NEHOD [onlinel. Praha: ÚZPLN, 2016 [cit. 2016-02-29]. Available from: http://www.uzpln.cz/pdf/ZC95hm3F.pdf

[2] Integrated Briefing System: NOTAM Query [online]. Jeneč: Aeronautical Information Service of the Czech Republic, 2016 [cit. 2016-03-12]. Available from: http://ibs.rlp.cz/home.do

[3] AisView 「onlinel. Jeneč: LIS ŘLP ČR, 2016 [cit. 2016-02-28]. Available from: http://AisView.rlp.cz/

[4] AisView Mobile [onlinel. Jeneč: LIS ŘLP ČR, 2016 [cit. 2016-02-28]. Available from: http://AisView.rlp.cz/index.mobile.php

[5] Aeronautical Infromation Services of the Slovak Republic [online]. Bratislava: Letové prevádzkové služby Slovenskej republiky, štátny podnik, 2016 [cit. 2016-02-28]. Available from: https://aim.lps.sk/web/

[6] VFReBULLETIN. AIS-Portal - PilotService [onlinel. Langen: DFS Deutsche Flugsicherung GmbH, 2016 [cit. 2016-03-01]. Available from:

https://secais.dfs.de/pilotservice/preparation/bulletin/bulletin_ edit_map.jsp

[7] Plos, V., Vittek, P.: Establishment of a System to Share Safety Information Between the "Small" Operators of Air Transport (General Aviation). In Mladá Veda 2012 - Veda a krízové situácie. Žilina: Fakulta špeciálneho inžinierstva Žilinskej univerzity v Žiline, 2012, p. 235-241. ISBN 978-80-554-0575-9.

[8] WebAUP ChartView. News - Portal Aeronautical Publications [online]. Frankfurt am Main: Zentrum Luftoperationen A 3 IIlc, 2016 [cit. 2016-03-01]. Available from: https://www.milais.org/gmaps.php

[9] AUP - AIRSPACE USE PLAN [onlinel. Wien: Airspace Management Cell - AMC, 2016 [cit. 2016-03-011. Available from: https://www.homebriefing.com/AesRepository/pdf/AUP_curre nt.pdf

[10] Elements of Airspace/Current. Polish Air Navigation Services Agency [online]. Airspace Management Cell - AMC, 2016 [cit. 2016-0301]. Available from: http://www.amc.pansa.pl/ strefy_amc_nowe.php?nr=7126

[11] Airspace Structure Austria [online]. Wien: Austro Control, 2016 [cit. 2016-03-01]. Available from: https://www.austrocontrol.at/en/atm/ aim_services/aim_products/airspace_structure

[12] Kraus, J., Němec, V.: Analysis of Instrument Approaches to GA Aerodromes in the World. MAD - Magazine of Aviation Development. 2014, vol. 2, no. 8, art. no. 1, p. 4-10. ISSN 1805-7578. 